\title{
A Study on Customer Attitude Towards Tamil Channels of Television in Theni Town
}

\author{
${ }^{1}$ M. NISHA, ${ }^{2}$ DR. S.CHITRA \\ ${ }^{1}$ M.Phil Scholar, ${ }^{2}$ Principal \& Assistant professor, Department of Commerce, \\ Nadar Saraswathi College of Arts \& Science, Theni, India.
}

\begin{abstract}
Entertainment industry is dynamically evolving and converging to the benefit of public. Today it is common in industrialized countries for a household to have at least one television. In fact, it is so common that is difficult to imagine a household without television. This shows just how important television is to understand how important television is. It can look at the variety of programmers and valuable content it alters and the purpose it serves in daily life. There are many different types of programmers on television. The viewers can watch a weather report to prepare for the day.
\end{abstract}

Key Words: Television, channels, customer attitude.

\section{INTRODUCTION}

Television has come to play an important role for education, information, social development and entertainment. The invention of television has made a great impact on the life of people through out the world. it is widely acknowledged as a powerful mass communication medium even though some of its undesirable effects, like addiction to viewing the 'Idiot box' hours on end are also manifest. Television influences people in their social behaviour, political views, buying habits and so on. Technological advancement of satellite television and cable television has further developed. In a country with a diverse of geographical, historical and cultural clusters spread across vast distances; the satellite television is a strong integrating factor for uniformed development. Now a days lot of Tamil channels is emerging as an information providers. This study undertakes the viewers attitude towards Tamilnadu Channels in Television in Theni district, Tamil Nadu.

Television has come to play an important role for education, information, social development and entertainment. The invention of television has made a great impact on the life of people through out the world. it is widely acknowledged as a powerful mass communication medium even though some of its undesirable effects, like addiction to viewing the 'Idiot box' hours on end are also manifest. Television influences people in their social behaviour, political views, buying habits and so on. Technological advancement of satellite television and cable television has further developed. In a country with a diverse of geographical, historical and cultural clusters spread across vast distances; the satellite television is a strong integrating factor for uniformed development.

\section{HISTORY}

The invention of television was the work of many individuals in the late 19th and early 20th centuries. The first practical transmissions of moving images over a radio system used mechanical rotating perforated disks to scan a scene into a time-varying signal that could be reconstructed at a receiver back into an approximation of the original image. Development of television was interrupted by the Second World War. After the end of the war, all-electronic methods of scanning and displaying images became standard. Several different standards for addition of color to transmitted images were developed, with different regions using technically incompatible signal standards. Television broadcasting expanded rapidly after World War II, becoming an important mass medium for advertising, propaganda, and entertainment. Television broadcasts can be distributed over the air by VHF and UHF radio signals from terrestrial transmitting stations, by microwave signals from Earth orbiting satellites, or by wired transmission to individual consumers by cable TV. Many countries have moved away from the original analog radio transmission methods and now use digital television standards, providing additional operating features and conserving radio spectrum bandwidth for more profitable uses. Television programming can also be distributed over the Internet.

\section{SCOPE OF THE STUDY}

Television channelled today is very congested and so many channels are trying to capture more respondents to view particular channel by having new technologies. Each channel is different in its particular channel by having new technologies. Each channel is different in its programmes 
and also the presentation of timings. Hence, it becomes essential to know what factors affects the respondents to watch a particular channel and how the respondents select the channels and on what basis they are going to select.

\section{OBJECTIVES OF THE STUDY}

1. To present the socio-economic of viewers of Tamil channels.

2. To examine the factors determining the attitude towards Tamil channels.

3. To analyze the customer satisfaction towards viewer of Tamil channels.

4. To providing possible suggestions to improve the service.

\section{PERCENTAGE ANALYSIS}

Percentage method has been used to analysis the profile of the respondents, the percentage method is used to know the accurate percentage of the collected data, it is easy to graph at through the percentage the framework percentage method is

Percentage of respondent $=$ Number of respondent

Total number of respondent

\section{FINDINGS OF THE STUDY}

\section{Gender}

The study reveals that out of 384 respondents 70 percent are female respondents and 30 percent of the respondents are male.

Age

Majority of the respondents 41 percent belongs to the age group of 40-60 years and only 6 percent of the respondents were above 60 years.

\section{Marital status}

Out of 384 sample respondents 65 percent are unmarried and 4 percent of the respondents are widow.

\section{REVIEW OF LITERATURE}

Plabita Das (2016) stated that never in the history of India, has the media been so much in focus and controversy as is today. In the wake of what they may call the post globalised and liberalized economy of the 1990s, the advent of information technology ere has been brought about a host of those radical changes, the socio-familial repercussion of which are considerably and unfavorably polluting very rich cultural, moral and ethical values of the people in the country. News studios have gradually become site where news is manufactured". Indeed television is more interested in a bid to increase their TRB ratings (Television Rating Points) are resorting to sensationalized journalism with a view to earn a competitive edge over the others. In this paper, I will try to assess how electronic media especially television has given journalism a new nature in India. Because it is a reason of major concern as people has witnessed frequent failure of the media to keep their responsibility to the people and their needs, aspirations and ambitions.

\section{ANALYSIS ANS INTERPRETATION}

\section{GENDER}

The sample respondents are classified on the basis of gender is presented in the table.

Gender wise classification of the respondents

\begin{tabular}{|c|c|c|c|}
\hline S. No & Gender & $\begin{array}{c}\text { Number of the } \\
\text { respondents }\end{array}$ & $\begin{array}{c}\text { Percentages of } \\
\text { the respondents }\end{array}$ \\
\hline 1. & Male & 116 & 30 \\
\hline 2. & Female & 268 & 70 \\
\hline \multicolumn{2}{|c|}{ Total } & $\mathbf{3 8 4}$ & $\mathbf{1 0 0}$ \\
\hline
\end{tabular}

Table shows that $268(70 \%)$ percentages are female respondents, male respondents are $116(30 \%)$ percentages. The male respondents are majority in this analysis.

AGE

The sample respondents are classified on the basis of age is presented in the Table.

Age wise classification of the respondents

\begin{tabular}{|l|l|l|l|}
\hline S. No & Age (in years) & $\begin{array}{l}\text { Number of the } \\
\text { respondents }\end{array}$ & $\begin{array}{l}\text { Percentage of } \\
\text { the respondents }\end{array}$ \\
\hline 1 & Below 20 & 122 & 31 \\
\hline 2 & $20-40$ & 156 & 41 \\
\hline 3 & $40-60$ & 82 & 21 \\
\hline 4 & 60 above & 22 & 6 \\
\hline & Total & $\mathbf{3 8 4}$ & $\mathbf{1 0 0}$ \\
\hline
\end{tabular}

From the Table shows that reveals that $156(41 \%)$ percent of the respondents belongs to the age group of under 2040,122 ( 31 ) percents of the respondents belongs to the age group of below $20,82(21 \%)$ percent of the respondents belongs to the age group of $40-60,22(6 \%)$ percent of the respondent belongs to the age of above 60 years respectively.

\section{MARITAL STATUS}

The sample respondents are classified on the basis of marital status presented the Table

\section{Marital status of respondents}

\begin{tabular}{|c|c|c|c|}
\hline S. No & Marital status & $\begin{array}{c}\text { Number of the } \\
\text { respondents }\end{array}$ & $\begin{array}{c}\text { Percentage of the } \\
\text { respondents }\end{array}$ \\
\hline 1. & Married & 132 & 34 \\
\hline 2. & Unmarried & 248 & 65 \\
\hline 3. & Widow & 4 & 0 \\
\hline \multicolumn{2}{|c}{ Total } & $\mathbf{3 8 4}$ & $\mathbf{1 0 0}$ \\
\hline
\end{tabular}

Table shows that $248(65 \%)$ percentages are unmarried respondents, married respondents are 132( 34\%) percentages, widow respondents are $4(1 \%)$ percentages. 


\section{HOURS A DAY ON WATCH TV}

The sample respondents are classified on the basis on type of connection in the Table

Hours a day on watch TV of the respondents

\begin{tabular}{|c|c|c|c|}
\hline S. No & Hours & $\begin{array}{c}\text { Number of the } \\
\text { respondents }\end{array}$ & $\begin{array}{c}\text { Percentage of the } \\
\text { respondents }\end{array}$ \\
\hline 1 & 2 hours & 16 & 4 \\
\hline 2 & 5 hours & 192 & 50 \\
\hline 3 & 7 hours & 144 & 38 \\
\hline 4 & Above 10 hours & 32 & 8 \\
\hline \multicolumn{2}{r}{ Total } & $\mathbf{3 8 4}$ & $\mathbf{1 0 0}$ \\
\hline
\end{tabular}

\section{INFERENCE}

From Table shows that 192(50\%) percent of the respondents are 5 hours a day on watch TV. 144(38\%) percent of the respondents are 7 hours a day on watch on TV. $32(8 \%)$ percent of the respondents are above 10 hours a day on watch on TV. 16 (4\%) percent of the respondents are 2 hours a day on watch on TV.

\section{CONCLUSION}

The present study analyzed the various factors relating to the consumers attitude towards Tamil channels and found that the consumers had a greater belief that television serials inform their viewers about their life style, purchasing behaviour, brands they need, updates with the products available in the market and keeps them in knowing about the changing fashions. Though there are some leading negative attitude among the viewers like TV ads if excessive, confuse them. Repetition of the ads frequently, irritate the viewers in watching those TV commercials and which in turn may have a negative impact about those products. It has also been found that consumers consider television serials and television advertisement as a medium that helps them in their effective life style and their purchase decisions.

\section{REFERENCES}

[1] Adler Rachard, Research on the effects of television advertising on children, Washington, D.C. National Science Foundation, 1979

[2] Adler, R and Fried Lander B.Z., Research on the effects of television advertising on children, Washington, D.C. National Science Foundations, 1975

[3] Allport, G.W., Pattern and Growth in Personality, Holt, Rinchart and Washingdon, New York, 1963.

[4] Barker, C.W. and Anderson, I.D. Principles of Retailing, McGraws Hill book Co., New York., 1941.

[5] Biplab S. Bose, Marketing Management, Himalaya Publishing House, New Delhi, 1998.

[6] Bliss, P. (ed), Marketing and the Attitudeal Sciences, Allyn and Bacon, inc., Boston, 1964.
[7] Brown, J.M, Berrien, F.K. and Russel, D.I., Applied Psychology, Amerind Publishing Co. Pvt. Ltd, New Delhi, 1972.

[8] Buckner, H., How British Industry Buys?., Hutchinson, London., 1967.

[9] Buskirk, R.H., Cases and Readings in Marketing, Holt, Rinchart and Winston, Inc., New York, 1970. 